\title{
Great personalities of medicine, great lessons
}

\section{Enrique Ruelas-Barajas, ${ }^{\text {* }}$ Martha E. Rodríguez-Pérez, ${ }^{2}$ and Ana C. Rodríguez-de Romo ${ }^{2}$}

${ }^{1}$ Medical School, Universidad Panamericana; ${ }^{2}$ Faculty of Medicine, Department of History and Philosophy of Medicine, Universidad Nacional Autónoma de México. Mexico City, Mexico

\begin{abstract}
The analysis of three characters corresponding to different spaces and times shows the close link between literature and the history of medicine. On one hand, Don Quixote of La Mancha, who reflects the thought of the last years of the Renaissance and that has been assimilated in contemporary Mexico. On the other hand, Doctors Miguel Francisco Jiménez and Rita Levi Montalcini, who lived in the $19^{\text {th }}$ and $20^{\text {th }}$ centuries, respectively. Despite the years that separate these three personalities, many elements in common are observed that do not lose their validity: the value that is given to health, ethics, tenacity and experience to attain successful results. All three characters refer to the medicine of their time, their achievements and the promotion of humanism, always inherent to medicine.
\end{abstract}

KEY WORDS: Medicine of the Renaissance. $19^{\text {th }}$ century medicine. Nobel Prize in Medicine.

\section{Grandes personajes de la medicina, grandes lecciones}

\section{Resumen}

El análisis de tres personajes correspondientes a espacios y tiempos diferentes muestra el estrecho vínculo entre la literatura y la historia de la medicina. Por un lado, don Quijote de la Mancha, quien refleja el pensamiento de los últimos años del Renacimiento y ha sido asimilado en el México contemporáneo. Por otro lado, los doctores Miguel Francisco Jiménez y Rita Levi Montalcini, quienes vivieron en los siglos XIX y XX, respectivamente. A pesar de los años que separan a los tres personaje, se advierten numerosos elementos en común que no pierden vigencia: el valor que se otorga a la salud, la ética, la tenacidad y la experiencia para obtener resultados exitosos, entre otros. Los tres personajes aluden a la medicina de su tiempo, los logros alcanzados y la promoción del humanismo, siempre inherente a la medicina.

PALABRAS CLAVE: Medicina del Renacimiento. Medicina del siglo XIX. Premio Nobel de Medicina.

\section{Introduction}

Culture, as a social phenomenon that endows our species with depth, is a dimension that should characterize the physician more than many others whose profession lacks the human nature of medicine. In these difficult pandemic times, culture also becomes a balm to palliate stress and uncertainty. This can be witnessed through the enormous amount of messages that circulate on social networks with pieces of music, classical and contemporary, images of paintings and literary and historical texts with the purpose to reassure spirits troubled by the situation and to strengthen those who are fortunate and can enjoy something enriching within the walls of confinement. When doctor Teresita Corona, president of the National Academy of Medicine of Mexico, proposed this topic to be included in the regular sessions program, no one could have suspected that this session
Correspondence:

*Enrique Ruelas-Barajas

E-mail: eruelas@ prodigy.net.mx
Gac Med Mex. 2020;156:465-472 Contents available at PubMed www.gacetamedicademexico.com 0016-3813/@ 2020 Academia Nacional de Medicina de México, A.C.. Published by Permanyer. This is an open access article under the CC BY-NC-ND license (http://creativecommons.org/licenses/by-nc-nd/4.0/). 
would coincide, not only with a pandemic, but also with its most critical moment. Dissemination of culture, from the National Academy of Medicine of Mexico, fully meets its purposes, for doctors and non-doctors.

This document addresses three celebrities from three historical moments in very different contexts. We will travel from the last years of the Renaissance to the $20^{\text {th }}$ century, going through the $19^{\text {th }}$ century. The first one of them is Don Quixote of La Mancha, a topic developed by Enrique Ruelas; the second personality in this chronology is Dr. Miguel Francisco Jiménez, presented by Martha Eugenia Rodríguez Pérez, and the third one is an exceptional woman whose features are described by Ana Cecilia Rodríguez de Romo.

Don Quixote of La Mancha is a very rich source of Renaissance medicine references through the enormous number of citations about remedies, interventions and considerations around doctors and the exercise of their profession that Miguel de Cervantes makes through his characters, mainly Don Quixote and Sancho Panza. This way, its author and its main protagonist become, as if they were one, a character of Renaissance medicine.

Next, the professional development of a Mexican physician is presented: Miguel Francisco Jiménez (1813-1875), who belonged to the academic elite of the $19^{\text {th }}$ century. Several facets are addressed, his teaching performance within the National School of Medicine, his work in academic associations, including the Medical Section of the Scientific Commission, considered the antecedent of current National Academy of Medicine of Mexico, where he was member of the board of directors. Finally, we focus on Jiménez's clinical work, whose contributions lie, among many others, in differentiating typhus from typhoid fever and in proposing a therapeutic resource for liver abscess.

Finally, the discovery of nerve growth factor (NGF) and the life of its discoverer, Italian doctor Rita Levi-Montalcini, constitute fascinating stories that marvelously depict how rich and productive the life and work of a human being can be. This work will briefly address the researcher obsessed with her science and her discovery, which clarified the origin and development of nervous tissue and made her deserving of the Nobel Prize.

\section{Medicine of the Renaissance in Don Quixote of La Mancha}

"Tell me, professor, which is the medical book that condenses all the knowledge, that will make me understand the pain, the suffering and joys of man. Tell me, professor, to that end, what book should I read? From which author?" These questions were asked by a student to Paul Ehrlich, a German doctor who discovered arsphenamine (Salvarsan), which allowed to effectively treat syphilis and for which he was awarded the Nobel Prize in Medicine in 1908. Ehrlich's answer was: "Read Don Quixote, son, by Miguel de Cervantes".

\section{Don Quixote: a fictional and real-life character}

Is it possible for Don Quixote of La Mancha to be regarded as a character of medicine? ${ }^{1}$ The answer is twice yes. Let's start by discussing the nature of Don Quixote as a character and then as a character of medicine. In the dictionary of the Royal Academy of the Spanish Language, a character is defined as "each one of the real or imaginary beings that appear in a literary, theatrical or cinematographic work". Don Quixote, obviously, is one. However, another meaning of the word is "singular person who stands out for his/ her peculiar way of being or acting". Through four centuries of fictitious presence, Don Quixote is for many a real character. It is someone who existed; for them, Don Quixote also meets the second definition.

As evidence of the second meaning of the word, I will cite the cultural phenomenon that saw its birth in Guanajuato on the mid-twentieth century. In 1953, at Plaza de San Roque in the city of Guanajuato, the play "Cervantes Entremeses. Imaginary world and reality of his world" was staged for the first time. The mise-enscène had enormous significance, with repercussions to this day, both for the open-air stage on the esplanade of a temple with a cross at the center, on a pedestal surrounded by crooked lanterns that distributed the scenic space, and for the singular staging of the show by Enrique Ruelas Espinosa, its creator and director. The play has been staged on that space for 67 years, despite the death of its initiator 33 years ago. To celebrate twenty years of uninterrupted presentations, in 1972, celebrating an International Cervantine Festival was decided, now also an event of the highest cultural category in the world, which has reached 47 years of life. This, and other important events that were unleashed around Miguel de Cervantes and his work in that city, such as the creation of the Don Quixote Iconographic Museum, motivated UNESCO to declare Guanajuato as "Cervantine Capital of America" in 2005. For this reason, Eulalio Ferrer, a distinguished 
man of letters and great Cervantes expert, donated a sculpture of Don Quixote to mark this event, which was placed on a pedestal at the center of the city; the place where it is found is visited by tourists, to whom some guides tell that it is the tomb where the remains of Don Quixote are buried. And some believe it.

In 2010, to use this belief as leverage, and at the same time to make evident the fictitious, although almost real life of the famous character, the Enrique y Alicia Ruelas Cervantine Foundation and Don Quixote Iconographic Museum decided to "bury" Don Quixote of La Mancha at that same place, of course, on its editorial version. The plate that marks the place reads like this:

Many years ago, the Knight of the Rueful Countenance ar-
rived in Guanajuato riding a golden horse of theatrical imag-
ination, tenacious bonhomie and enormous enthusiasm from
Enrique Ruelas, Eulalio Ferrer and many members of the
Guanajuato community. In the base of his sculpture, but not
as in a grave, lies the Guanajuato Edition of Don Quixote of
La Mancha. Whoever claims that Don Quixote is buried in
this land will never lie. In the City of Guanajuato, its inhabi-
tants buried him at this place as a colossal and transparent
treasure to the glory of Miguel de Cervantes Saavedra, of
human spirit and universal culture.

This way, Don Quixote, the fictional character, merges with the real character, and for many, with its author, a celebrity of universal literature. Thus, to speak of Don Quixote of La Mancha as a character of medicine, it is necessary to speak about the real person who created him: Miguel de Cervantes Saavedra (Fig. 1).

\section{Celebrities of Renaissance medicine}

Cervantes was born in Alcalá de Henares in 1547 and died in 1616. He lived just at the final stage of Renaissance, if the arbitrarily-assigned time to this period is considered to range from 1450 to 1600 , and for some, up to 1616, precisely the year of Cervantes's death and, almost on the same date, also of William Shakespeare's death. He coincided in time with forgers not only of this fascinating period but of art and science of our days. Contemporaries of Cervantes were Lope de Vega, Quevedo, Michelangelo Buonarotti, Velázquez, El Greco, Vesalius, Harvey, Bacon, Leewenhook, Hook, Paré, Descartes, Galileo and Kepler. This way, Cervantes went through revolutions in anatomy, physiology, surgery, microscopy and in clinical practice. He was a worthy Renaissance citizen. In addition, his father was a doctor, and thus he surely

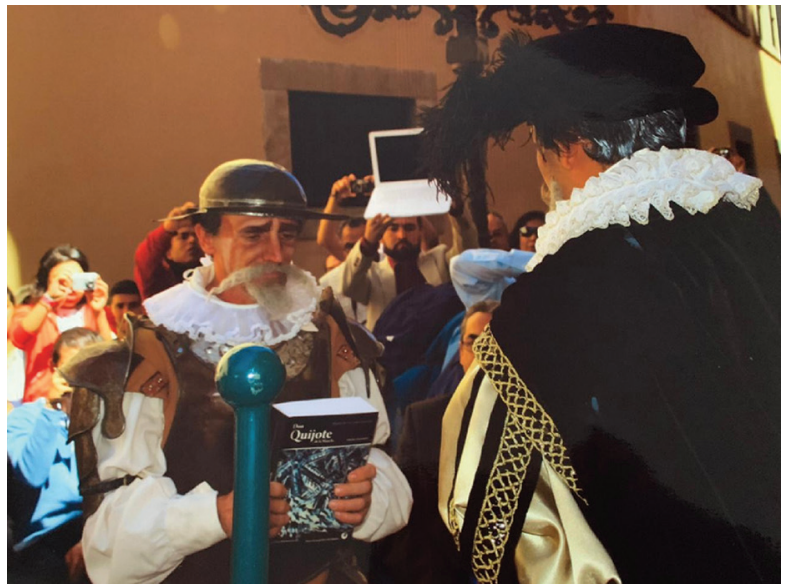

Figure 1. Don Quixote's burial in Guanajuato.

received his influence and certain knowledge that he finely wove in his work. Despite having been a soldier and tax collector, Cervantes was a cultured man.

This is why Don Quixote of La Mancha, as a book and as a fiction of an endearing knight-errant, is a character not only of literature, but also of medicine. Don Quixote somehow defines himself as a doctor when he says: "The knight-errant... must be a physician, and above all a herbalist, so as in wastes and solitudes to know the herbs that have the property of healing wounds...." Two-hundred and eighty-one medical terms appear 4,226 times. The most cited word is "blood". Dermatological, infectious, neurological, ophthalmological and urinary signs, among others, appear in different characters of the work. Wounds are mentioned everywhere. Don Quixote says: "Wounds received in battle confer honor instead of taking it away." "... and if I make no complaint of the pain it is because knights-errant are not permitted to complain of any wound, even though their bowels be coming out through it."

Remedies and interventions are also present throughout the work. Plants such as chicory, oleander, rosemary, rhubarb, spurge and verbena are recommended, or the famous Fierabrás balm. Ointments such as marsh-mallow, basilicon and white ointment are prescribed. The recipes contain names, mode of prescription and instructions for use. Interventions such as drains, sutures, enemas and different types of bloodletting are practiced. Sancho Panza, as usual, utters, among others, a comical phrase about doctors: "I'd rather have my fill of gazpacho than be subject to the misery of a meddling doctor who starves me to death"; and an enlightened saying when invested 
governor of the Barataria Island: "I'll not leave a doctor in the whole Island; at least of those I know to be ignorant; for as to learned, wise, sensible physicians, them I will reverence and honor as divine persons".

There is no doubt that Don Quixote of La Mancha, as a literary work, as an almost real fictional character, and as an expression of an upright Renaissance man, is a character of medicine. They both are: Don Quixote and Miguel de Cervantes. Indeed, as Ehrlich told his student, to know medicine one has to approach Miguel de Cervantes's Don Quixote.

\section{Miguel Francisco Jiménez and $19^{\text {th }}$ Century clinical practice}

Miguel Francisco Jiménez (1813-1875), who was born in the state of Puebla, was a multifaceted man with great historical awareness, hence we can have information from his own writings about his activities as a professor, member of academic associations, editor and as a clinician. His professional performance went through the different events the country was experiencing, Santa Anna's dictatorship, the North American invasion, the French intervention, during which he supported the Second Empire. Jiménez believed in Maximilian's government, hoping that it would bring socio-political stability and culture to the country. Thus made he sure that Finance Minister José María Iglesias knew: “... I have faith that an order could be founded that, truly accepted by all, would forever end the eternal anarchy that is consuming us". ${ }^{2}$ In fact, he was one of the four personal doctors the Emperor had, in addition to Federico Semeleder, Samuel Basch and Rafael Lucio.

\section{Miguel Francisco Jiménez performance at the School of Medicine}

Jiménez graduated as a surgeon in September 1838, and two months later, he began to work as a professor at the School of Medicine of Mexico City. He taught four subjects, Anatomy, Anatomy Prosector, Internal Pathology and Internal Clinic. In addition, he served as secretary of the institution, and thus he got to know well its functioning.

As an Internal Clinic professor he showed multiple skills. He published his lessons in specialized press, he taught his students the method for establishing a diagnosis: inspection, palpation, percussion and auscultation, as Jiménez in turn had learned from his physiology teacher, Manuel Carpio. At the opening of his class, on that subject, Jiménez, based on Bouillard, claimed that "the method is, without dispute, the supreme regulator of all things...", ${ }^{3}$ hence he became a pioneer in the treatment of liver abscesses.

\section{Academic associations}

Within the framework of the French intervention, the Scientific, Literary and Artistic Commission of Mexico was established in 1864, which was made up of several sections, including the sixth, Medical Sciences, whose leaders were Carlos Alberto Ehrmann (president), Julio Clement (first vice president) and Miguel F. Jiménez (second vice president). After the retreat of the French command to Europe and of Ehrmann's retirement, in 1865, the medical section became independent and was named the Medical Society of Mexico, under the presidency of Jiménez, a Society that in 1870 would change its name to Academy of Medicine of Mexico. Thus, this organization had Ehrmann as its first president and Jiménez as the second, who held this position four times: in 1865, 1866, 1870 and 1872 , given his deep interest in science. Furthermore, within the framework of this organization, Jiménez served as president of the Publications Commission that published Gaceta Médica de México as of September 15, 1864.

In 1870, when Jiménez served again as head of the association, he expressed his interest in the country's situation, proposing that each member presented an original work by turns at Wednesday's sessions, where health problems of the country would be analyzed (Fig 2). ${ }^{4}$

\section{Jiménez, a clinician par excellence}

Miguel Francisco Jiménez was a talented clinician. $\mathrm{He}$ had great teachers. Internationally, we might say that he carefully followed the advances of the French school, which had the merit of having created and taught the anatomo-clinical mentality, where the essential element of disease is the anatomical lesion and organ alterations examination, as advocated by Corvisart and Laennec, among others. In addition, Jiménez particularly studied the lessons of Magendi, an experimental physiology pioneer. ${ }^{5}$ As for his national teachers, Jiménez was a disciple of Manuel Carpio, who introduced Laennec's knowledge and contributions into Mexico, such as auscultation, the approach to heart diseases and the stethoscope. 


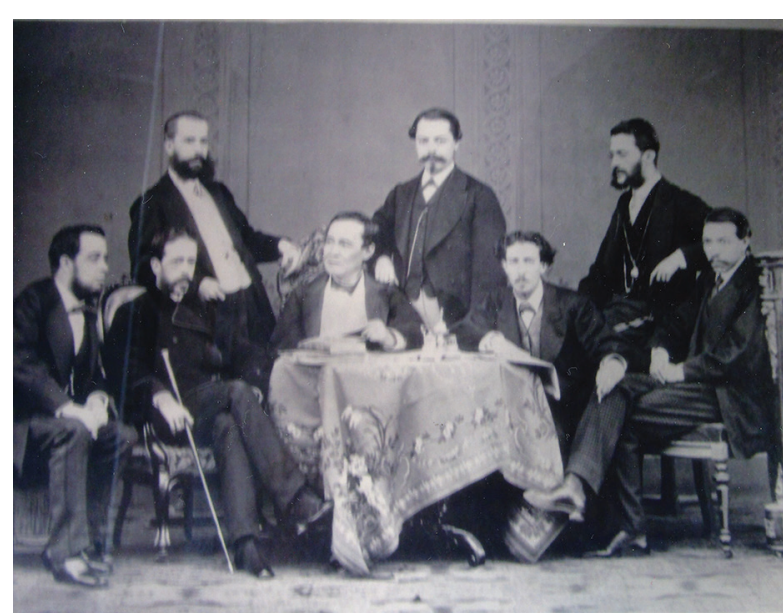

Figure 2. Miguel F. Jiménez, sitting, center, at the Family Medicine Society, 1870.

By auscultating and using the stethoscope, Jiménez was able to learn what was occurring inside the human body, which appeared to have been concealed. Thus, he expressed: "Thanks to the immortal discoveries of Aüembrugger and Laennec, the doctor has been given the power to see down to the interior of organs as if the human body was transparent ....".

In particular, two contributions by Miguel F. Jiménez to the clinical area are presented, the difference between typhus and typhoid fever and, on the other hand, a therapeutic resource for amoebic liver abscess.

Regarding the first contribution, Jiménez studied typhus or tabardillo for many years, since it was a disease associated with poverty and unhealthy conditions present in Mexico. By consulting the books of French authors that made reference to typhoid fever, Jiménez clarified doubts. Both diseases were intertwined because the term fever was confusing. From way back came the error of turning a clinical sign into a pathological entity, ${ }^{6}$ consisting, among other things, of a complex of alterations such as stupor, dyspnea episodes, pain and diarrhea, in addition to a temperature increase in the patient body; thus, Jiménez managed to elucidate similarities and differences between typhus and typhoid fever. In this regard, he pointed out: "I believe I have the honor of having been the first one to draw attention on the differences that are noted between the tabardillo from Mexico and the fever from Europe..."?

With regard to liver abscess, Jiménez studied it because it represented a common disease in the country. For 18 years he looked after patients at Hospital de San Andrés, which had been transformed into an emergency space for public scientific practices. ${ }^{8} \mathrm{He}$ was careful to write about his observations as clinical lessons in the newspaper La Unión Médica de México. In this regard, he expressed:"

... well, a fluid that has developed in the liver after an acute inflammation, with the circumstances that are referred to, must be pus; and, consequently, the disease that we study today must be classified like this: abscesses of the liver.

After analyzing numerous clinical cases of patients with liver abscess, Jiménez raised his hypothesis regarding the etiology. He proposed that liver disease was more prevalent in warm places, such as Mexico, than in cold climates. ${ }^{9}$ The predominant gender and age group was men between 28 and 58 years of age, and as a history of the condition, he found severe indigestion, intense physical activity, episodes of anger and, mainly, alcoholism, referring in particular to the consumption of fermented pulque.

Once the condition was identified, Jiménez proposed a therapeutic resource, artificial drainage through trocar puncture, which managed to reduce mortality from abscesses by $60 \%$. Thanks to his way of working under a rigorous methodology, Jiménez positioned himself as a great clinician who transcended Mexican borders.

\section{Rita Levi-Montalcini: in praise of imperfection}

Rita Levi-Montalcini was awarded the 1986 Nobel Prize in Medicine for having discovered the nerve growth factor (NGF). As difficult as it may seem, in the mid-20 th century, much was unknown about the development of the nervous system; how nerve cells differentiate from each other, how their axons establish synapses, or what is the nature of the chemical messages by means of which they communicate. The discovery of NGF answered those questions and continues answering others, since evidence has been found of its relationship with the etiology of diseases such as Alzheimer, Huntington, Parkinson and multiple sclerosis.

\section{How and why the interest in Rita Levi-Montalcini?}

A few years ago, Rita Levi-Montalcini's autobiography entitled In Praise of Imperfection ${ }^{10}$ came into my hands. Rita was an excellent writer and the fresh and charming reading of the book caught me from the very first pages. Later, as a historian of medicine, one of my lines of interest was the study of the factors that 
surround the phenomenon of scientific discovery: the social, political, economic and historical circumstances and, obviously, the figure of researchers themselves, their personality, their biography, their context, etc. Thus, the character Rita Levi-Montalcini and NGF caught my interest and attention for a long time and, even, an example of this is a chapter of my book ¿Eres exitoso? La historia y los científicos responden (Are you successful? History and scientists answer). ${ }^{11}$

Rita Levi-Montalcini was born on April 22, 1909 in Turin, Italy, in the bosom a highly cultivated Jewish family, and died on December 30, 2012 in Rome, at the age of 103. Until the end she was lucid, although she was almost blind and deaf. In those last years she used to say: "it is inevitable for the body to wrinkle, but not the brain. Keep your brain full of hope, active, make it work and it will never deteriorate".

Rita was influenced by a father who was of avant-garde thinking, but careful to uphold family traditions, and by a mother who was cultivated but obedient to the power roles within marriage; both were cultured and intellectually brilliant. She had four siblings, but her twin Paola (1909-2000) had a special place in her life and was also her best friend. In fact, she dedicated her autobiography to her.

Her decision not to marry in order to entirely devote herself to science is known among her biographers. Indeed, Rita never married, but when she was very young she had a suitor, also a medical student, whom she was very fond of, but who passed away. It is difficult knowing what would have really happened should that young man not have died. Rita Levi-Montalcini's opinion to choose a partner is quite attractive; according to her, to decide to share one's life with someone, it is essential to consider the differences in temperament, education and cultural interests.

With regard to Rita and Paola, their father had decided to send them to a girls' school where they would learn to be good wives and mothers. However, at the age of 20, Rita expressed her wish to study medicine. Her father was reluctant but supported her; in 1930, Levi-Montalcini was admitted to the Turin School of Medicine, where there were only seven women amid 300 men. Her sister Paola also revealed herself against her father's plans; she dedicated herself to painting and became a renowned artist; she didn't get married either.

\section{Scientific career}

In 1932, when she was in second year of undergraduate medical studies, she entered histologist Giuseppe Levi's
(1872-1965) laboratory, who taught her the classic staining technique with silver salts devised by Santiago Ramón y Cajal (1852-1934) and that Rita would use all her life. With Levi she met her lifelong friends, Salvador Luria (1912-1991) and Renato Dulbecco (1914-2012). Years later, all three colleagues would be awarded the Nobel Prize: Luria for clarifying viral replication mechanism and genetic structure and Dulbecco for discovering the interaction of tumor viruses and cell genetic material. Scientific genealogies are highly attractive: in the case of Levi-Montalcini, it would begin with Ramón y Cajal; in turn, she was Levi's student, and his discipline with regard to study was to be continued with her students, currently scattered throughout the scientific world.

When she graduated in 1936, Levi-Montalcini thought of specializing in neurology and psychiatry, which was not possible because Benito Mussolini's Manifesto of Race barred Jews from universities. Thus, with Giuseppe Levi and in hiding, she continued her research on the nervous system in a makeshift home laboratory, which she described as of "Robinson Crusoe" style. With her mentor Levi she published some works; one in particular, in 1946, caught the attention of Viktor Hamburguer (1900-2001), a German scientist, an embryology scholar of those days. The article addressed the effect of extirpation, in chicken embryos, of the yolks that give rise to the development of the limbs. Hamburger wrote Levi to invite his student to repeat this experiment at his laboratory in Saint Louis Missouri, in the United States. Rita Levi-Montalcini arrived at Hamburger's laboratory in 1947 and would definitely return to her country already being very old.

In Rome, she founded a research institute, devoted herself to support science, received multiple distinctions and honors, was a senator for life, Italy's ambassador at the United Nations Food and Agriculture Organization (FAO), developed extensive philanthropic work in Ethiopia and, with her savings, promoted women's education in underdeveloped countries. Not only did she write scientific articles, she also wrote highly successful literary pieces that, besides being entertaining, teach life lessons. I already mentioned her autobiography In Praise of Imperfection (Fig. 3). Other books include Ace in the sleeve, The mind galaxy, Without oil and against the wind and Having the courage to know, among others.

The saga of the discovery of NGF is a variety of acute observations, coincidences, fortuitous events, strokes of luck and circumstantial factors magnificently taken advantage of by a genuine scientist. In this presentation, I will not address Rita Levi-Montalcini's 


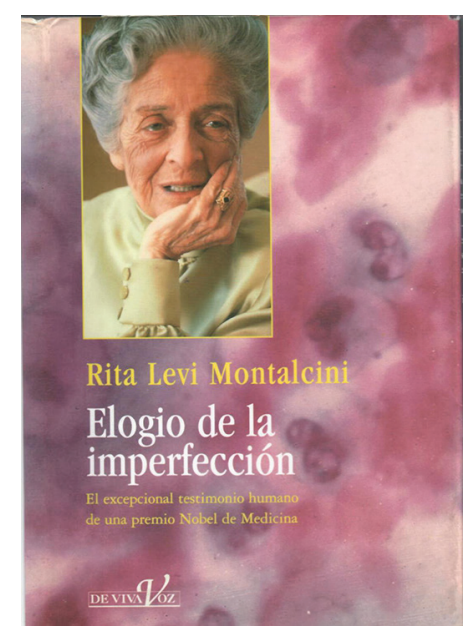

Figure 3. Rita Levi-Montalcini's book cover.

discovery, which would be the subject of another work; ${ }^{12}$ rather, I want the message of the genuine, exceptional scientist who lived only for her science to permeate.

\section{Nobel Prize}

In 1986, at age 77, Rita Levi-Montalcini received the Nobel Prize for discovering NGF. The fact that the Nobel was not also awarded to Viktor Hamburger continues to cause controversy, since it was at his laboratory that Levi-Montalcini conducted the experiments. Personally, I have multiple explanations, but when the scientist herself was asked for the reason, she replied: "Viktor was a scholar, who always did an excellent job, but he never discovered the nerve growth factor". NGF was Rita Levi-Montalcini's reason for living. The way she refers to the factor in her speech at the Nobel banquet is so eloquent and extraordinary, that it is qualified as the most beautiful piece of literature that has ever been written in reference to the distinction that all scientists dream of. In her autobiography, she narrates the following:10

On Christmas Eve 1986, NGF appeared in public under large floodlights, amidst the splendor of an immense festively decorated hall in the presence of the royals of Sweden, of princes, of ladies with rich ball gowns and gentlemen in tuxedos. Wrapped in a black mantle, he bowed before the king and, for a moment, lowered the veil covering his face. We recognized each other in a matter of seconds when I saw him looking for me among the applauding crowd. He then replaced his veil and disappeared as suddenly as he had appeared. Has he returned to his wandering life in the forests inhabited by the spirits that roam at night on the shores of the frozen lakes of the North, where I spent so many lonely and enchanted hours of my youth? Will we see each other again? Or was that instant the fulfillment of my desire of many years to meet him, and I have henceforth lost trace of him forever?

Rita Levi-Montalcini and NGF symbolized a unit, a single being, they were Siamese twins impossible to separate at the risk of either of both dying. The exceptional researcher's finding gave rise to an understanding of basic processes of human body's nature. NGF destruction or low production is the cause of nervous diseases, some of them incurable. Levi-Montalcini proved that NGF stimulates both peripheral motor and sensory cell lines in the spinal cord, and also neurons involved in higher brain functions. Furthermore, it is involved with the endocrine and immune nervous system, since it is produced in hypothalamic nuclei and brain and extra-brain endocrine populations, and not only at the spinal cord. NGF is a neurotrophin and a cytokine, and it also appears to be related to oncogenes. With this factor, Levi-Montalcini concluded that the central and peripheral nervous systems are not rigidly programmed and wondered about the real role of peripheral tissues and organs at the medullary nerve centers that innervate them.

Robert Provine, one of her students, and whom I had the opportunity to interview, shared with me that Rita Levi-Montalcini was one of the most creative, demanding and luminous figures of $20^{\text {th }}$ century's biological sciences. She possessed an impressive scientific intuition, an iron will, a strict code of ethics in the laboratory, a working habit, and exceptional discipline. Organized and tenacious, she worked long hours a day. She did not tolerate stupidity, she was temperamental and her mood was easily perceived. Charming, educated, high-spirited, beautiful, elegant all her life, distinguished, fashion-conscious, with an aristocratic, "chic" style. Provine describes her as being slender as a model, wearing elegant two-piece suits or sleeveless high-neck dresses, combined with an exquisitely tasteful jacket that she herself designed in silk and Italian brocade; all this combined with stilettos, her mother's pearl necklace, a thick gold bracelet and an antique brooch. Before starting her class, she liked to put a drop of perfume behind each ear. In the words of Robert Provine, Rita Levi-Montalcini demonstrated how rich a long existence can be in scientific career and how creativity is ageless.

\section{Lessons}

Now, in reverse chronological order, we can conclude the following: 
The discovery of NGF is a good example of contemporary scientific findings, resulting from the work of groups of researchers supported by sophisticated technology. However, among these scientists, there is often one who brings experiments and ideas to their ultimate consequence. Such was the case of Rita Levi-Montalcini, who set out to understand the origin and development of nervous tissue in the embryonic process and thus discovered NGF. Levi-Montalcini used to say that she had not a higher intelligence, but she did have a particular intuition in the laboratory. Apart of her own statement, it is clear that she used to work intensely, possessed a magnificent training, great discipline, order, patience, perseverance and an enormous resistance to adversity and frustration, with all these qualities crystallizing in a highly successful life in the world of scientific research and in obtaining the Nobel Prize.

Miguel Francisco Jiménez was a distinguished physician who belonged to the learned sphere of his time. $\mathrm{He}$ was fond of teaching, knowledge dissemination and, essentially, of clinical work, through which the ethics and scientific rigor he worked with are noted, as well as the importance he attributed to experience. A host of years of work allowed him to go from practical solutions to epistemological solutions to the health problems he confronted. Jiménez carried out a scientific work that involves personalities, institutions, academic associations, publications and research itself.

Finally, although many of the remedies and interventions cited in Cervantes's work for healing have been left behind in the times of history, the greatest lessons of Don Quixote of La Mancha for today's doctors would be his bonhomie, philanthropy, loyalty, honesty, respect and many other virtues. In short, through his crazy sanity, we should have to keep always learning from his love for others.

\section{Acknowledgements}

To Doctor Teresita Corona, president of the National Academy of Medicine of Mexico, for the invitation to present this symposium.

\section{Conflict of interests}

The authors declare that they have no conflicts of interest.

\section{Funding}

The authors did not receive any sponsoring to carry out this article.

\section{References}

1. De Cervantes-Saavedra M. Don Quijote de la Mancha [Guanajuato edition]. Mexico: Museo Iconográfico del Quijote; 2010.

2. Fernández-del Castillo F. Antología de escritos histórico-médicos del Dr. Francisco Fernández del Castillo. Mexico: Departamento de Historia y Filosofía de la Medicina, Facultad de Medicina, Universidad Nacional Autónoma de México; 1978.

3. Jiménez MF. Discurso pronunciado por D. M. F. Jiménez al comenzar las lecciones de clínica en la Escuela de Medicina. Mexico: Periódico de la Sociedad Filoiátrica de México; 1844.

4. Rodríguez ME. Academia Nacional de Medicina de México. Notas históricas. Mexico: Academia Nacional de Medicina de México/Permanyer; 2018.

5. Laín-Entralgo P. Historia de la medicina. Spain: Salvat; 1982.

6. Somolinos-D'Ardois G. La obra del Dr. Miguel F. Jiménez. Las conferencias Miguel Jiménez e Ignacio Chávez. Mexico: Academia Nacional de Medicina/Intersistemas; 2015.

7. Jiménez MF. Tabardillo. Gac Med Mex. 1864:1:205-216.

8. Jiménez MF. Tratamiento de los abscesos del hígado. Gac Med Mex. 1866;2:6-11.

9. Jiménez MF. Abscesos del hígado. Lecciones de clínica médica. Mexico: La Unión Médica de México; 1857.

10. Levi-Montalcini R. Elogio de la imperfección. Spain: Ediciones B; 1999.

11. Rodríguez-de Romo AC. ¿Eres exitoso? La historia y los científicos responden. Mexico: Facultad de Medicina, Universidad Nacional Autónoma de México; 2017.

12. Rodríguez-de Romo AC. Chance, creativity and the discovery of the nerve growth factor. J Hist Neurosci. 2007;16:268-287. 